\title{
ROLE OF MOTIVATIONAL FACTORS ON EMPLOYEE RETENTION IN SERVICE SECTORS: A STUDY WITH SPECIAL REFERENCE TO CHENNAI CITY
}

\author{
E. Angelena Asha Chelliah ${ }^{1} \square$ (1) and Dr. Syed Rafiq Ahmed ${ }^{2}$ - \\ ${ }^{1}$ Assistant Professor, Department of Commerce, Ph.D Research Scholar(PT), Department of Commerce, Sir Theagaraya \\ College, Bharathiar University, Chennai, 600 021, Tamil Nadu, India \\ ${ }^{2}$ Associate Professor \& Head, Department of Commerce, The New College, Chennai, India
}
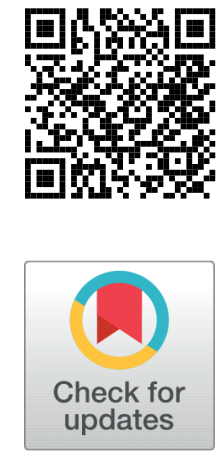

Received 26 May 2021

Revised 7 June 2021

Published 30 June 2021

Corresponding Author

E. Angelena Asha Chelliah, aasha_1

04@rediffmail.com

DOI 10.29121/

granthaalayah.v9.i6.2021.3967

Funding: This research received no specific grant from any funding agency in the public, commercial, or not-for-profit sectors.

Copyright: (C) 2021 The Author(s). This is an open access article distributed under the terms of the Creative Commons Attribution License, which permits unrestricted use, distribution, and reproduction in any medium, provided the original author and source are credited.

\section{ABSTRACT}

Aim: The paper aims to measure the role of motivational factors on employee retention practices in service sectors in Chennai city.

Data Sources: Primary and Secondary data used for the study. The Primary data sourced from the employees working in service sectors. The employees are contacted in electronic mode and obtained the responses from employees.

Sample size \& Method: The sample for this study consisted of 600 employees drawn based on a simple random sampling method from the service sector. Out of 600 samples, 39 samples were rejected due to inadequate information provided by the employees. Finally, 561 samples were used for analysis.

Findings: The study originated that the employees are satisfied with the motivational factors, i.e., compensation and Rewards, Pleasant Work Environment, Leadership styles, Training and Development, and Fringe benefits, offered by the service sectors in Chennai city. In addition, the paper also identified a significant association between motivational factors and employee retention practices in the service sectors. Furthermore, the study concluded that there is no significant difference among the employee's working sectors concerning the average score of motivational factors offered by the service sectors in the study region. The study created a significant association between motivational factors and the personal profile of employees working in the service sector in Chennai city. The study also initiates that there is a significant impact of motivational factors on employee retention in service sectors in the study region.

Keywords: Employee Retention, Compensation, Leadership And Supervision, Engagement, Work Environment 


\section{INTRODUCTION}

The service segment plays a considerable role in the economic development of our nation Nawaz et al. (2020). India's services sector covers various activities namely trade, transport, storage and communication, hotel and restaurants, financing, insurance, real estate, business services, community, social and personal services, and services associated with construction. The enhanced of the Services Sector in India is an exclusive example of leap-fogging conventional models of economic growth. Within a short duration of 50 years since independence, India's contribution to the country's GDP is the lion's share of over $60 \%$. Nevertheless, it unmoving utilizes only $25 \%$ of the labor force. Consequently, agriculture and manufacturing continue to sustain most of employed populace. The service organizations are focusing on implementing effective employee retention strategies.

Employee retention is the competence of the organizations to preserve its employees. A simple statistic can represent employee retention. Nevertheless, many consider employee retention is connecting to the efforts by which employers attempt to retain employees in their employees G. Vijayakumar and Shanthini (2020). Employee retention is the competence of the firm to preserve its employees. An easy statistic can indicate employee retention. Nevertheless, many believe employee retention connects to the efforts by employers attempt to keep employees Kumar and Kaushik (2013). The employee's efficiency is honestly attached to the outcome and performance of individual business units. In both sectors, the management gives due weightage to the employee contribution, which brings good organization level N. Vijayakumar and Tharanya (2020). In the globalized era, engaging business has become an extremely competitive game. It is true not only for the product industry but also for the service industries G. Vijayakumar (2020). Employee Retention is an ongoing effort. It is one of the major responsibilities of the management to enable the employees to enhance their skill levels, understand their diversified thought processes, and motivate them Vijayakumar (2016). Therefore, the present study focuses on measuring the role of motivational factors on employee retention practices in service sectors in Chennai city.

\section{LITERATURE REVIEW}

The employee retention function is not guaranteed still when distinguished employee satisfaction is executed Paulsen and Kaddoura (2020), Hee and Rhung (2019) Exhibits the intrinsic and extrinsic motivational determinants that stimulate employees and the systems to maintain capabilities in the organization. Sawaneh and Kamara (2019) every organization should prioritize essential actions to seal employee vacancies and build up vigorous employee retention policies to avoid additional employees from leaving Sabbagha et al. (2018). Fahim (2018) grounds that the work of best HRM rehearses are regarded as a surprising essential. Subhash and Kundu (2017) steady workplace presumes a necessary job in anticipating worker 
maintenance. Valaei and Rezaei (2016) doctors have clear inclinations concerning to work environment inspiration. Imna et al. (2015) discovered that three human asset practices. Nagabhaskar (2014) pressing in affecting worker maintenance are monetary prizes, work qualities the executives, and work-life balance. Vijayakumar (2016) originated that there is a positive and noteworthy relationship between's Motivational variables and Employee Retention.

\section{FACTORS OF EMPLOYEE MOTIVATION}

\subsection{COMPENSATION AND REWARD}

Kahn (1990) sees that worker's degree of job is an element of their impression of the advantages. When representatives are inspired, option to satisfy the clients' needs and together accomplish the organization's objectives (Bowen, 2000). Reward is the most significant motivational attributes that contribute to retaining employees in the organization (Michael, S. 2008)

Compensation is an essential characteristic of employee engagement that stimulates an employee to attain more work and individual development. It engages both financial and non-financial rewards. Petcharak (2002) stated that populace is motivated by extending wealth because of several different reasons; the need to provide the necessities of life encourages most people. Michael S. (2008), competitive pay package is the most significant motivational variable contributing to retaining employees in the organization.

\subsection{TRAINING \& DEVELOPMENT}

Nguyen and Duong (2020) explains empirical evidence by demonstrating that training and development, job satisfaction, and job performance directly affect young employee retention in Vietnam organizations. The study also indicates that job satisfaction, job satisfaction, and job performance in Vietnam organizations help to convey the effect of young employee retention. Management should begin to create an environment where critical information has been generously communicated. Therefore, this will retain the employees and have a positive impact on organizational productivity Singh (2008). The training process plays an essential role in the process of motivation. It supports the employees from deteriorating due to a need of updated knowledge and mapping the skill level.

\subsection{WORKING ENVIRONMENT}

The working environment is low-graded due to need of all the basic facilities Singh (2008). Besides, a lousy supervisor creates a hostile working ecosystem, thereby prompting highly qualified and talented employees to leave the job. There is no use in planning motivation for high performance Bowey (2005). Managers should also clutch a healthy working environment. Pessaran and Tavakoli (2011) revealed that a 
pleasant working environment is most eminent for employee retention.

\section{OBJECTIVES OF THE STUDY}

- To assess the role of motivational factors on Retention Practices in service sectors in Chennai city

\section{STATEMENT OF HYPOTHESIS}

1. The Employees are not satisfied with the motivational factors offered by the service sectors in Chennai city

2. There is no significant difference among the employees working sectors concerning the average score of motivational factors offered by the service sectors in the study region

3. There is no correlation between Motivational Factors and Employee Retention practices in the service sector in Chennai city

4. There is no association between the level of mutational factors and the personal profile of employees working in the service sector in Chennai city

\section{METHODOLOGY}

The current study's core objective is to assess the role of motivational factors on employee retention practices among the employees working service sectors in Chennai city. The study used both secondary and primary data-the research conducted in Chennai city. The primary data is gathered from the employees working service sectors, i.e., banking, Insurance, and IT \& ITES. In each industry, 200 questionnaires were distributed; overall, 600 questionnaires were distributed. Out of 600 samples, 39 samples were rejected due to inadequate information provided by the employees. Finally, 561samples were used for analysis. The employees were contacted through the electronic mode and generate responses. The instrument first tested by conducting a pilot study. The value of Cronbach's alpha is 0.862 ; hence, the same questionnaire was employed for the final research, keeping in view the instrument's high score of reliability and validity. The primary sources from target respondents were analyzed using descriptive, One-sample t-test, Pearson correlation, chi-square test, and analysis of variance. The data were scrutinized using SPSS 21.0 version.

\section{RESULTS AND DISCUSSION}

Table 1 Demographic Profile of Respondents $(n=561)$

Demographic Profile Frequency Percent

Continued on next page 


\begin{tabular}{|c|c|c|}
\hline \multicolumn{3}{|c|}{ Table 1 continued } \\
\hline \multicolumn{2}{|c|}{ Gender } & \multirow[b]{2}{*}{58.6} \\
\hline Male & 329 & \\
\hline Female & 232 & 41.4 \\
\hline \multicolumn{2}{|c|}{ Age (Years) } & \\
\hline Up to 30 & 170 & 30.3 \\
\hline $31-40$ & 162 & 28.9 \\
\hline $41-50$ & 131 & 23.4 \\
\hline Above 50 & 98 & 17.5 \\
\hline \multicolumn{2}{|c|}{ Educational qualification } & \\
\hline UG & 210 & 37.4 \\
\hline PG & 195 & 34.8 \\
\hline Professional & 156 & 27.8 \\
\hline \multicolumn{2}{|c|}{ Marital status } & \\
\hline Single & 197 & 35.1 \\
\hline Married & 364 & 64.9 \\
\hline \multicolumn{2}{|c|}{ Experience (in years) } & \\
\hline$<3$ & 147 & 26.2 \\
\hline $3.1-6.0$ & 204 & 36.4 \\
\hline $6.1-9.0$ & 150 & 26.7 \\
\hline$>9$ & 60 & 10.7 \\
\hline \multicolumn{2}{|c|}{ Working Sector } & \\
\hline Banking & 184 & 32.8 \\
\hline Insurance & 197 & 35.1 \\
\hline IT \& ITES & 180 & 32.1 \\
\hline
\end{tabular}

Source: Primary data

Table 1 reveals the personal profile of employees working in service sectors in Chennai city. Out of 561 employees' majorities, 58.6\% of the employees are male category, and $41.4 \%$ of the employees are female groups. In the connection age group of employees, majority $30.3 \%$ of the employees are up to 30 years, followed by $28.9 \%$ of the employees are in the age group of $31-40$ years, $23.4 \%$ of the employees are in the age group of $41-50$ years, and $17.5 \%$ of the employees are in the age group of above 50 years. Regarding Educational qualification, the majority 37.4.\% of the employee's educational background is under-graduates, followed by $34.8 \%$ of the employee's educational qualification background is post-graduates, and $27.8 \%$ of the employee's educational experience is professional courses. The study results also indicate that most $64.9 \%$ of the employees are married, and $35.1 \%$ of the employees are single category. Regarding the work experience, the majority, 36.4\%, has 3.1- 6.0 years. The study also exhibits that the majority, $35.1 \%$ of the employees, are from the insurance sector, followed by $32.8 \%$ of the employees from banking and $32.1 \%$ of the IT \& ITES sector employees.

Null Hypothesis-1

The Employees are not satisfied with the motivational factors offered by the service sectors in Chennai city 
Table 2 One-sample t-test for the satisfaction level of Motivational factors offered by the service sectors

\begin{tabular}{|c|c|c|c|c|c|c|}
\hline Banking & & $\begin{array}{l}\text { Compensatio] } \\
\text { \& Rewards }\end{array}$ & $\begin{array}{c}\text { Pleasant } \\
\text { Work Envi- } \\
\text { ronment }\end{array}$ & $\begin{array}{c}\text { Leadership } \\
\text { styles }\end{array}$ & $\begin{array}{c}\text { Training \& } \\
\text { Development }\end{array}$ & $\begin{array}{c}\text { Fringe } \\
\text { Benefits }\end{array}$ \\
\hline & $\mathrm{N}$ & 184 & 184 & 184 & 184 & 184 \\
\hline & Mea & 3.45 & 3.78 & 3.99 & 3.96 & 3.93 \\
\hline & SD & .595 & .709 & .711 & .736 & .760 \\
\hline & $\mathrm{t}$ & 21.667 & 24.416 & 28.408 & 26.886 & 25.618 \\
\hline & $\mathrm{p}$ & $<0.001^{* *}$ & $<0.001^{* *}$ & $<0.001^{* *}$ & $<0.001^{* *}$ & $<0.001^{* *}$ \\
\hline \multirow[t]{6}{*}{ Insuran } & & $\begin{array}{l}\text { Compensatio] } \\
\text { \& Rewards }\end{array}$ & $\begin{array}{c}\text { Pleasant } \\
\text { Work Envi- } \\
\text { ronment }\end{array}$ & $\begin{array}{c}\text { Leadership } \\
\text { styles }\end{array}$ & $\begin{array}{c}\text { Training \& } \\
\text { Development }\end{array}$ & $\begin{array}{c}\text { Fringe } \\
\text { Benefits }\end{array}$ \\
\hline & $\mathrm{N}$ & 197 & 197 & 197 & 197 & 197 \\
\hline & Mea & 3.37 & 3.70 & 3.84 & 3.78 & 3.83 \\
\hline & SD & .631 & .766 & .780 & .822 & .802 \\
\hline & $\mathrm{t}$ & 19.399 & 21.960 & 24.062 & 21.894 & 23.240 \\
\hline & $\mathrm{p}$ & $<0.001^{* *}$ & $<0.001^{* *}$ & $<0.001^{* *}$ & $<0.001^{* *}$ & $<0.001^{* *}$ \\
\hline $\begin{array}{l}\text { IT \& } \\
\text { ITES }\end{array}$ & & $\begin{array}{l}\text { Compensatio] } \\
\text { \& Rewards }\end{array}$ & $\begin{array}{c}\text { Pleasant } \\
\text { Work Envi- } \\
\text { ronment }\end{array}$ & $\begin{array}{c}\text { Leadership } \\
\text { styles }\end{array}$ & $\begin{array}{c}\text { Training \& } \\
\text { Development }\end{array}$ & $\begin{array}{c}\text { Fringe } \\
\text { Benefits }\end{array}$ \\
\hline & $\mathrm{N}$ & 180 & 180 & 180 & 180 & 180 \\
\hline & Mea & 3.41 & 3.73 & 3.83 & 3.88 & 3.94 \\
\hline & SD & .633 & .771 & .793 & .784 & .765 \\
\hline & $\mathrm{t}$ & 19.198 & 21.335 & 22.489 & 23.541 & 25.317 \\
\hline & $\mathrm{p}$ & $<0.001^{* *}$ & $<0.001^{* *}$ & $<0.001^{* *}$ & $<0.001^{* *}$ & $<0.001^{* *}$ \\
\hline
\end{tabular}

Source: Primary data

Note: ${ }^{* *}$ denotes significant at $1 \%$ level

Table 2 describes the results of a One-sample t-test for the satisfaction of Motivational factors offered by the service sectors in the study area. In the banking, insurance, and IT \& ITES sector, the mean values of fundamental elements are $>3$, which indicates the employees positively agreed on the motivational factors. Since the pvalues of entire motivational factors are $<0.01$. Therefore, the $\mathrm{H}_{0}$ was rejected, and the study concluded that the employees are satisfied with the motivational factors offered by the service sectors in the study region.

Null Hypothesis-2

There is no significant difference among the employees working sectors concerning the average score of motivational factors offered by the service sectors in the study region

Table 3 ANOVA test for employees working sectors concerning the average score of motivational factors offered by the service sectors

$\begin{array}{llllll}\text { Sectors } & \text { N } & \text { Mean } & \text { SD } & \text { F } & \text { p } \\ \text { Banking } & 184 & 3.82 & .550 & 1.923 & \end{array}$


Table 3 continued

\begin{tabular}{lllll}
\hline Insurance & 197 & 3.70 & .606 & 0.147 \\
IT \& ITES & 180 & 3.75 & .612 & \\
\hline
\end{tabular}

Table 3 reveals the results of the ANOVA test for employees working sectors concerning the average score of motivational factors offered by the service sectors. The F \& p for employees working sectors concerning the average score of motivational factors provided by the service sectors is $1.923 \& 0.147$. The $\mathrm{p}$-value is $>0.05$.Therefore, the null hypothesis was accepted at a $5 \%$ level. Hence the study confirmed that there is no significant difference among the employee's working sectors concerning the average score of motivational factors offered by the service sectors in the study region. The study also originated that the employees working in the banking sector (3.82) were significantly satisfied with the motivational factors. It followed by IT \& ITES (3.75), and Insurance (3.70)

\section{Null Hypothesis: 3}

There is no correlation between Motivational Factors and Employee Retention practices in the service sector in Chennai city

Table 4 Karl Pearson Correlation test for Motivational Factors and Employee Retention $(n=561)$

\begin{tabular}{llllllll} 
& & CR & PWE & LS & TD & FB & RS \\
CR & Pearson Correlation & 1 & $.567^{* *}$ & $.470^{* *}$ & $.363^{* *}$ & $.400^{* *}$ & $.475^{* *}$ \\
\hline PWE & Pearson Correlation & $.567^{* *}$ & 1 & $.573^{* *}$ & $.595^{* *}$ & $.563^{* *}$ & $.474^{* *}$ \\
LS & Pearson Correlation & $.470^{* *}$ & $.573^{* *}$ & 1 & $.646^{* *}$ & $.602^{* *}$ & $.615^{* *}$ \\
TD & Pearson Correlation & $.363^{* *}$ & $.595^{* *}$ & $.646^{* *}$ & 1 & $.653^{* *}$ & $.531^{* *}$ \\
FB & Pearson Correlation & $.400^{* *}$ & $.563^{* *}$ & $.602^{* *}$ & $.653^{* *}$ & 1 & $.511^{* *}$ \\
\hline RS & Pearson Correlation & $.475^{* *}$ & $.474^{* *}$ & $.615^{* *}$ & $.531^{* *}$ & $.511^{* *}$ & 1 \\
\hline
\end{tabular}

$\mathrm{CR}=$ Compensation \& Rewards; PWE= Pleasant Work Environment; LS= Leadership styles; $\mathrm{TD}=$ Training \& Development; FB=Fringe Benefits; and SR=Employee Retention Strategies

Table 4 emphasizes Karl Pearson's test for association between motivational factors and retention strategies among the employees in service sectors in Chennai city. Since the p-value of whole factors is $<0.01$, it is statistically significant at a $1 \%$ level.Therefore, the framed null hypothesis was rejected and confirmed a significant association between motivational factors of employees and retention strategies among the employees working in service sectors in Chennai city.

Level of Motivational Factors among the Employees working in Service sectors in Chennai city

Table 5 Level of Motivational Factors among the Employees working in Service sectors

\begin{tabular}{cccc}
\hline Working Sector & $\begin{array}{c}\text { Level of Motivational factors offered by Service } \\
\text { sectors } \\
\text { Ledium }\end{array}$ & High & Total \\
\hline & & Continued on next page
\end{tabular}




\begin{tabular}{ccccc}
\hline Table 5 continued & \multicolumn{3}{c}{} \\
\hline Banking & 39 & 94 & 51 & 184 \\
& $21.2 \%$ & $51.1 \%$ & $27.7 \%$ & $100.0 \%$ \\
\hline Insurance & $28.3 \%$ & $33.8 \%$ & $35.2 \%$ & $32.8 \%$ \\
& 59 & 90 & 48 & 197 \\
\hline IT \& ITES & $29.9 \%$ & $45.7 \%$ & $24.4 \%$ & $100.0 \%$ \\
& $42.8 \%$ & $32.4 \%$ & $33.1 \%$ & $35.1 \%$ \\
& 40 & 94 & 46 & 180 \\
\hline Total & $22.2 \%$ & $52.2 \%$ & $25.6 \%$ & $100.0 \%$ \\
& $29.0 \%$ & $33.8 \%$ & $31.7 \%$ & $32.1 \%$ \\
& 138 & 278 & 145 & 561 \\
& $24.6 \%$ & $49.6 \%$ & $25.8 \%$ & $100.0 \%$ \\
\hline
\end{tabular}

Table 5 describes the results of Level of Motivational Factors among the Employees working in Service sectors in Chennai city. In the banking sector, $51.1 \%$ ofthe employees have medium-level satisfaction with motivational factors. $27.7 \%$ of employees have the high-level pleasure of motivational factors, and $21.2 \%$ of the employees have low-level motivational factors. In the Insurance sector, the majority, $45.7 \%$ of the employees, have medium level satisfaction with motivational factors. It followed by $29.9 \%$ of employees have low-level satisfaction of motivational factors, and $24.4 \%$ of the employees have high-level satisfaction of motivational factors. In the IT and ITES sectors, the majority, $33.8 \%$ of the employees, have medium-level satisfaction with motivational factors. It followed by $25.6 \%$ of employees have high-level satisfaction of motivational factors, and $22.2 \%$ of the employees have low-level satisfaction of motivational factors.

\section{Null Hypothesis-4}

There is no association between the level of motivational factors and the personal profile of employees working in the service sector in Chennai city

Table 6 Chi-square test for association between level of motivational factors and demographic profile of employees working in the service sector

\begin{tabular}{cccc}
\hline & Chi-square value & df & p \\
\hline Gender and Level of Motivational factors & 10.199 & 2 & $0.006^{* *}$ \\
\hline Age and Level of Motivational factors & 26.036 & 6 & $<0.001^{* *}$ \\
$\begin{array}{c}\text { Educational Qualification and Level of } \\
\text { Motivational factors }\end{array}$ & 11.321 & 4 & $0.023^{*}$ \\
$\begin{array}{c}\text { Marital status and Level of Motivational } \\
\text { factors }\end{array}$ & 17.268 & 2 & $<0.001^{* *}$ \\
Experience and Level of Motivational factors & 20.983 & 6 & 0.002
\end{tabular}

Table 6 reveals the Chi-square test results for the association between the level of motivational factors and demographic profile of employees working in the service sector in the study region. Since the p-value of fundamental aspects of motivational factors and demographic profile of employees are $<0.05$. The framed null hypothesis was rejected and concluded that there is a significant association between motiva- 
tional factors and the personal profile of employees working in the service sector in Chennai city.

\section{CONCLUSION}

The present research is proposed to measure the Role of Motivational Factors on Employee Retention in Service Sectors in Chennai city. The study originated that the employees are satisfied with the motivational factors, namely Compensation and Rewards, Pleasant Work Environment, Leadership styles, Training and Development, and Fringe benefits, offered by the service sectors in Chennai city. The current paper also identified a significant association between motivational factors and employee retention practices in the service sectors. In addition, the study concluded that there is no significant difference among the employee's working sectors concerning the average score of motivational factors offered by the service sectors in the study region. The study also originated that the employees working in the banking sectors (3.82) were significantly satisfied with the motivational factors. It followed by IT \& ITES (3.75) and Insurance (3.70). Furthermore, the study created a significant association between motivational factors and the personal profile of employees working in the service sector in Chennai city. The study also initiates that there is a significant impact of motivational factors on employee retention in service sectors in the study region.

\section{REFERENCES}

Bowey, J. A. (2005). Predicting Individual Differences In Learning To Read.

Fahim, M. G. A. (2018). Strategic Human Resource Management And Public Employee Retention. Review Of Economics And Political Science, 3(2), 20-39. Retrieved from Https:// Doi.Org/10.1108/Reps-07-2018-002

Hee, O. C., \& Rhung, L. X. (2019). Motivation and Employee Retention among Millennials in Malaysia. International Journal of Academic Research in Business and Social Sciences, 9(2), 876-884. Retrieved from https://dx.doi.org/10.6007/ijarbss/v9-i2/5629

Imna, M., , \& and, Z. H. (2015). INFLUENCE OF HUMAN RESOURCE MANAGEMENT PRACTICES ON EMPLOYEE RETENTION IN MALDIVES RETAIL INDUSTRY. International Journal of Accounting and Business Management, 4(2), 50-80. Retrieved from https:// dx.doi.org/10.24924/ijabm/2015.04/v3.iss1/50.80

Kahn, W. A. (1990). PSYCHOLOGICAL CONDITIONS OF PERSONAL ENGAGEMENT AND DISENGAGEMENT AT WORK. Academy of Management Journal, 33(4), 692-724. Retrieved from https://dx.doi.org/10.2307/256287

Kumar, A., \& Kaushik, M. (2013). Retention Of Bpo Employees In India. European Journal of Business And Management, 5(30), 109-114.

Nagabhaskar, M. (2014). Employee Retention And Engagement Is Critical For Organization Because Employees Are The Driving Force To Achieve The Development And Accomplishment Of The Organization's Goals And Objectives., 4, 1193-1196.

Nawaz, N., Gajenderan, V., \& Vasuki, K. (2020). Impact Of Hrm Practices Towards The Employee Engagement In Private Banks. International Journal On Emerging Technolo- 
gies, 11(5), 245-251.

Nguyen, C., \& Duong, A. (2020). The Impact Of Training And Development, Job Satisfaction And Job Performance On Young Employee Retention. International Journal of Future Generation Communication And Networking, 13(3), 373-386.

Paulsen, \& Kaddoura, M. H. (2020). Corporate Social Responsibility And Its Effect On Employee Retention Intention: A Quantitative Study Of Employee Needs, Motivation Factors And Hygiene Factors.

Pessaran, D., \& Tavakoli, S. S. (2011). To Identify The Employees' Motivation Of Parsian Hotels In Tehran:(The 2nd Half Of.

Sabbagha, M. D. S., Ledimo, O., \& Martins, N. (2018). Predicting staff retention from employee motivation and job satisfaction. Journal of Psychology in Africa, 28(2), 136-140. Retrieved from https://dx.doi.org/10.1080/14330237.2018.1454578

Sawaneh, I. A., \& Kamara, F. K. (2019). An Effective Employee Retention Policies as a Way to Boost Organizational Performance. Journal of Human Resource Management, 7(2), 41-41. Retrieved from https://dx.doi.org/10.11648/j.jhrm.20190702.12

Singh, B. D. (2008). Managing Conflict And Negotiation. Excel Books India.

Subhash, C., \& Kundu, L. (2017). Article Information: Effects Of Supportive Work Environment On Employee Retention: Mediating Role Of Organizational Engagement. International Journal of Organizational Analysis. Int J Logistics Management. Retrieved from Https://Doi.Org/10.1108/09574090910954864

Valaei, N., \& Rezaei, S. (2016). Job satisfaction and organizational commitment. Management Research Review, 39(12), 1663-1694. Retrieved from https://dx.doi.org/10.1108/mrr -09-2015-0216

Vijayakumar. (2016). Employee Motivational Factors And It S Impact On. Pezzottaite Journals, 6(2), 3011-3018.

Vijayakumar, G. (2020). Impact Of Leadership Towards The Organizational Performance: A Study With Special Reference To Service Sectors. In Chennai City. Tathapi -Ugc Care Journal, 19, 106-115.

Vijayakumar, G., \& Shanthini, B. N. (2020). Influence of Motivational Factors on Employee Retention among the Sales Managers in the Private Sector Insurance companies in Chennai City. SUMEDHA JOURNAL OF MANAGEMENT, 9(1), 52-52. Retrieved from https://dx.doi.org/10.46454/sumedha/9.1.2020.5

Vijayakumar, N., \& Tharanya, N. (2020). Assessment Of Organizational Effectiveness: A Comparative Study In Between Public And Private Sector. International Journal Of Psychosocial Rehabilitation, 24(10), 1808-1817. 